\title{
The occurrence of diseases and their relationship with passive immune transfer in Holstein dairy calves submitted to individual management in southern Brazil
}

[Ocorrência de doenças e sua relação com a transferência de imunidade passiva em bezerras Holandês criadas em sistema individual no sul do Brasil]

\author{
M.A.A. Weiller ${ }^{1}$, D.A. Moreira ${ }^{2}$, L.F. Bragança², L.B. Farias ${ }^{2}$, \\ M.G. Lopes ${ }^{2}$, F.R.P. Bruhn ${ }^{3}$, C.C. Brauner ${ }^{2}$, E. Schmitt ${ }^{2}$, \\ M.N Corrêa $a^{2}$, V.R. Rabassa ${ }^{2}$, F.A.B. Del Pino ${ }^{2}$
}

\begin{abstract}
${ }^{1}$ Instituto Federal de Educação, Ciência e Tecnologia do Rio Grande do Sul - Bento Gonçalves - RS ${ }^{2}$ Nucleo de Pesquisa, Ensino e Extensão em Pecuária - Universidade Federal de Pelotas - Pelotas, RS ${ }^{3}$ Faculdade de Veterinária - Universidade Federal de Pelotas - Pelotas, RS
\end{abstract}

\begin{abstract}
Calves are extremely dependent on colostrum intake for the acquisition of passive immunity. This study aimed to determine the occurrence of diarrhea and respiratory diseases and the impact of Failure of Passive Immune Transfer (FPIT) on the health and zootechnical performance of Holstein dairy calves in individual management. This study has been carried out in five commercial farms in Rio Grande do Sul State, Brazil, from March 2017 to January 2018. In this study, 131 calves were followed from birth to 60 days of age. Total Plasmatic Protein (TPP) has been performed to determine passive immune transfer quality in 53 calves (53/131). A daily clinical follow-up has been accomplished aiming at diagnosing diseases and their incidences, and zootechnical measures such as withers height, width of the croup and weight have been evaluated. FPIT rate was $32.07 \%$, diarrhea occurrence and respiratory diseases were $77.9 \%$ and $49.6 \%$, respectively. FPIT increased the chances of calves presenting diarrhea and developing respiratory diseases, but no differences on zootechnical performance were found. The frequency of FPIT is still high and is a factor that corroborated the increased risk for diarrhea and respiratory disease but did not influence the performance of calves in the preweaning phase.
\end{abstract}

Keywords: health, neonatology, immunoglobulins, diarrhea, respiratory disease

\section{RESUMO}

Bezerras são extremamente dependentes da ingestão de colostro para adquirir imunidade passiva. Este estudo teve o objetivo de determinar os índices de ocorrência de diarreia e de doença respiratória, assim como o impacto da falha na transferência de imunidade passiva (FTIP) no desenvolvimento de doenças e no desempenho zootécnico de bezerras Holandês criadas em sistema individual. O estudo foi desenvolvido em cinco propriedades comerciais no Rio Grande do Sul, Brasil, entre março de 2017 e janeiro de 2018. Assim, 131 bezerras foram acompanhadas, do nascimento aos 60 dias de idade. Em 53 animais, foi realizada avaliação de proteínas plasmáticas totais para determinar a qualidade na transferência de imunidade passiva. Acompanhamento clínico diário foi realizado, a fim de diagnosticar doenças e suas incidências, assim como avaliações zootécnicas, como altura de cernelha, largura de garupa, perímetro torácico e peso. O percentual de FTIP foi 32,07\%, a ocorrência de diarreias e de doenças respiratórias foi, respectivamente, 77,9\% e 49,6\%. A FTIP aumentou as chances de as bezerras apresentarem diarreia e doenças respiratórias, mas não alterou o desempenho zootécnico. Conclui-se que a frequência na FTIP ainda é elevada, fator que corroborou o aumento do risco para as diarreias e doença respiratória. Apesar disso, a FTIP não influenciou no desenvolvimento das bezerras na fase de aleitamento.

Palavras-chave: saúde, neonatologia, imunoglobulinas, diarreia, doença respiratória 


\section{INTRODUCTION}

Bovine neonates are agammaglobulinemic at birth and are, therefore, dependent on absorption of immunoglobulins (Ig) delivered through maternal colostrum (MacFarlane et al., 2015). The Igs in colostrum (IgG, IgA and IgM) are considered essential for good neonate performance and health, especially in the first month of life (Smolenski et al., 2007). When there is an inadequate transfer of Igs through colostrum, it characterizes Failure of Passive Immune Transfer (FPIT); this occurs when serum IgG concentrations are below $10 \mathrm{mg} / \mathrm{mL}$ in neonates between 1 and 9 days of age (Wilm et al., 2018), or when Total Plasma Protein (TPP) concentrations are below $5.5 \mathrm{~g} / \mathrm{dL}$ between 24 and 48 hours of life (Buczinski et al., 2018). In addition, colostrum is a source of important cells such as monocytes, lymphocytes, neutrophils, eosinophil (Gomes et al., 2017), and also cytokines (Chase et al., 2008) and growth factors (Godden, 2008) which also has important function on neonate's health.

An adequate transfer of passive immunity is important because calves with FPIT are more susceptible to developing enteric diseases (Lora $e t$ al., 2018), and calves which survive are more susceptible to develop other diseases, such as respiratory complex disease, which negatively impact performance and lead to economic losses (Raboisson et al., 2016). Thus, inadequate amounts of colostrum administered to calves resulted in higher mortality rates, more severe diarrhea, and lower weight gain in affected calves (Quigley et al., 1995). Weight gain in dairy cattle is extremely important, since it directly influences the age at first service and subsequently at first calving, thus impacting animal productivity and profitability (Morrison et al., 2013).

Once FPIT is responsible for a higher level of disease, longer rearing period, and increased use of antimicrobials in calves, it constitutes an economic, public health, and animal welfare issue. There is a need in most different world regions to determine the incidence of FPIT and its real impact on disease development, considering the different types of calf management that can be employed. Although individual pens reduce the direct exchange of pathogens between animals, this does not avoid environment effects on disease occurrence (Costa et al., 2016).
Thus, we conduct this cohort study aimed to determine the impact of FPIT on diarrhea, respiratory disease and zootechnical performance of Holstein dairy calves from Rio Grande do Sul state submitted to individual management.

\section{MATERIAL AND METHODS}

An observational cohort study was carried out in five commercial dairy farms, in Rio Grande do Sul state, Brazil, from March 2017 to January 2018. During this period, daily follow-up was accomplished on 131 Holstein calves from birth to 60 days of age. One of the farms was located in the South region $\left(32^{\circ} 16^{\prime} \mathrm{S}, 52^{\circ} 32^{\prime} \mathrm{W}\right)$, and the others in the Northwest region $\left(27^{\circ} 51^{\prime} \mathrm{S}, 53^{\circ} 46^{\prime}\right.$ $\mathrm{W})$, all under humid subtropical climate. The number of farms to involved was conveniently established in order to meet the minimum number of calves needed for the study.

The farms included in the study were similar in terms of cow breed reared (Holstein), herd size (200-600 lactating cows), production (around $35 \mathrm{~L} / \mathrm{cow}$ ), housing (individual calf pen or stake system), feeding (total mixed ration) and milking (milking parlor) systems, management of calving (use of calving pen; parturition monitored by the farmer at least twice a day; calf separated from dam immediately after birth, up to 6 hours) and calves (navel disinfection using iodine; at least 4 $\mathrm{L}$ of colostrum of the own dam provided by nipple-bottle; single housing until at least $5 \mathrm{wk}$ of age, receiving water ad libitum, concentrate was provided the calves from the three/fourth day of life according to NRC recommendation).

All of the farms had veterinary assistance, and all data were collected in the same period as well. The procedures performed during this study have been previously authorized by the Animal Experiment Ethics Committee of Federal University of Pelotas, under registration 283962018.

Health status from 131 calves under study were monitored on each visit to the farm, daily or eventually every two days, from birth to 60 days of age, and always by a trained veterinarian. For this purpose, initially all animals were observed, and at a sign of any clinical changes, such as drooping ears, apathy, tachypnoea, presence of secretions, or reduction in milk intake (according to trainer's report), calves were evaluated 
clinically. During clinical examination heart rate, respiratory rate, rectal temperature, capillary perfusion time, mucosal staining, cough reflex, attitude (alert/apathetic), and presence of ocular/nasal secretions were evaluated to set a clinical diagnosis. Physiological parameters under examination were those proposed by Dirksen et al. (1993).

Among 131 animals included in this study, 53 calves were randomly selected (according to parturition) and submitted to an evaluation of passive immunity transfer. The sample size needed to develop this cohort study (53) was based on Fleiss et al. (2013), considering an incidence of $75 \%$ between unexposed and $99 \%$ between exposed, based on the expected incidence of diarrhea in these groups, through the OpenEpi program, with $95 \%$ significance and $80 \%$ power (Dean et al., 2014).

Thus, from passive immune transfer diagnosis, two cohorts were formed: one consisting of calves that received satisfactory passive immune transfer (36 calves), and another cohort of animals that did not receive satisfactory passive immune transfer (17 calves); this was done to compare the incidence of health problems or differences in zootechnical parameters between cohorts.

Passive immunity transfer quality was evaluated in 53 calves (53/131). To that end, blood samples were collected via puncture of the jugular vein, from 24 to 48 hours after colostrum intake, using a $10 \mathrm{~mL}$ Vaccutainer tube with EDTA anticoagulant (CRAL, São Paulo, Brazil). Immediately after blood collection, samples were stored in Styrofoam containing ice and sent to the laboratory for centrifugation. Blood was centrifuged for 10 minutes at 3500rpm. After centrifugation, plasma was aspirated using a Pasteur pipette (KASVI, Paraná, Brazil). TPP concentrations were evaluated in a portable optical ATC refractometer (Instrutherm, São Paulo, Brazil), which had been previously calibrated with distilled water and used as recommended by the manufacturer. Passive immunity was considered a failure in calves that had TPP concentrations below $5.5 \mathrm{~g} / \mathrm{dL}$ (Buczinski et al. 2018).

Regarding clinical diagnosis, diarrhea was based on observing aqueous feces (presence of feces in the perineal region or the hock region) and presence of associated clinical signs, such as dehydration, apathy, increased intestinal peristalsis, fever, tachycardia, tachypnea, and increased capillary perfusion time. Respiratory disease cases were diagnosed through pulmonary auscultation and suggestive clinical signs of respiratory disease, such as fever, dyspnea, tachypnea, presence of nasal and/or ocular secretion, apathy or inappetence (Lorenz et al., 2011).

From clinical follow-up and diseases diagnosis, it was possible to obtain incidence rate (number of animals that became sick during the study/total of animals $(n=131)) \times 100$, mortality rate (number of animals that died/total of animals $(n=131)) \times 100$, recurrence rate (number of calves that became sick more than once/number of calves that became sick) $\mathrm{x} 100$, and lethality (number of animals that $\mathrm{died} /$ number of animals that became sick) x 100, for each of the diseases observed throughout the study (diarrhea and respiratory diseases). Sick animals were treated according to protocols adopted by each farm, and always under veterinarian supervision.

Birth weight was measured in all 131 calves. In 117 calves (131 calves except 14 that died), zootechnical parameters such as withers height, width of the croup, thoracic perimeter, and body weight were measured. Besides, we compared these zootechnical parameters between cohorts aiming to determine if FPIT may influence the results. Measurements were performed at birth, and at 7, 14, 21, 28 and 60 days of age. For width of the croup and withers height measurements, a hypo-meter was used. For thoracic perimeter we used a tape measure. Calf weights were estimated with a heart girth tape placed vertically at the point of the elbow (Heinrichs et al., 2007). All parameters were evaluated in triplicate, and measurement means were recorded in a specific worksheet.

For each calf, we calculated the Average Dailygain (ADG) dividing weight gain over 60 days by 60 . At the end of the experiment we calculated the number of calves that could double their body weight in 60 days of age, subtracting the final weight from birth weight. From data obtained in the field, we determined the incidence, mortality and lethality for both diarrhea and respiratory disease. Comparisons of these incidences between cohorts were performed using 
Pearson's chi-square test. Relative risk was calculated (incidence of exposed / incidence of unexposed) with $95 \%$ of confidence interval. For both, we used the Open Epi program.

Using graph Pad Prism 5, we performed survival analysis to compare curves between cohorts using Kaplan-Meier method. Similarly, continuous variables were compared between cohorts (weight gain, ADG, wither height, width of the croup, thoracic perimeter) using ANOVA repeated measures; these were done only after testing for normality and homoscedasticity of variance by Kolmogorov-smirnov and Levene tests, which are prerequisites for the analysis. Differences were considered significant when $P$ value $\leq 0.05$, and when $P$ values were between 0.06 and 0.09 , it was considered a tendency.

\section{RESULTS}

FPIT rate was $32.07 \%(n=17 / 53)$. Total Plasmatic Protein (TPP) values followed by standard error for each of the groups, with FPIT $v s$. without FPIT, were $4.97 \pm 0.08 \mathrm{~g} / \mathrm{dL}$ vs. $6.82 \pm 0.16 \mathrm{~g} / \mathrm{dL}$, respectively. Disease incidence throughout the study was $77.9 \%(102 / 131)$ for diarrhea and $49.6 \%$ (65/131) for respiratory diseases. When we analyzed diarrhea incidence between calves with or without FPIT, we observed differences between groups $(\mathrm{P}=0.05)$; all calves with FPIT (17/17) had at least one episode of diarrhea during the first 60 days of age, whereas in those who did not present FPIT, the incidence was $75.0 \%$ (27/36).
Failure of immunoglobulin transfer increased relative risk of calves presenting diarrhea throughout the study by $33 \% \quad(\mathrm{RR}=1.33,95 \%$ $\mathrm{CI}=1.03-1.59$; Table 1), when contrasted to those without FPIT. Calves with FPIT had risk estimated at $94.7 \%$ in developing diarrhea (IC:73.52\% - 100\%). In relation to reoccurrence, animals with FPIT presented 2.11 times greater risk of presenting a new case of diarrhea $(\mathrm{RR}=2.11,95 \% \mathrm{CI}=1.09-4.09, \mathrm{P}=0.03$; Table 1$)$

Linked to respiratory disease, we also observed a difference $(\mathrm{P}=0.04)$ between animals with or without FPIT: $76.5 \%$ (13/17) of calves with FPIT showed clinical signs of respiratory diseases, whereas the incidence was lower $(47.2 \% ; 17 / 36)$ in those without FPIT. FPIT increased the risk of developing respiratory disease by $62 \%(\mathrm{RR}=1.62$, 95\% CI=1.04-2.50; Table 2), and calves with FPIT had risk estimated in $76.47 \%$ (IC: $53.23 \%$ $90.95 \%$ ) to develop respiratory disease. There were no differences in recurrence of respiratory diseases $(\mathrm{P}=0.28)$ between cohorts.

Survival curves for the interval from birth to 60 days of life showed that calves with FPIT have greater rate of diarrhea compared with calves without FPIT (hazard ratio: 2.68; 95\% CI=1,275,65; Figure 1). For respiratory diseases, there were no differences in survival curves for the interval from birth to 60 days of life between cohorts (with or without FPIT; Figure 2).

Table 1. Incidence and relative risk of disease and death in Holstein dairy calves with or without Failure of Passive Immunity Transfer (FPIT) in southern Brazil

\begin{tabular}{|c|c|c|c|c|c|c|c|}
\hline Parameter & $\begin{array}{l}\text { Overall } \\
(\mathrm{n}=131)\end{array}$ & $\begin{array}{l}\text { Cohort incidence } \\
(\mathrm{n}=53)\end{array}$ & $\begin{array}{c}\text { With FPIT } \\
(n=17)\end{array}$ & $\begin{array}{c}\text { Without FPIT } \\
(n=36)\end{array}$ & $\begin{array}{c}\text { Relativ } \\
\text { e risk }\end{array}$ & $95 \% \mathrm{CI}$ & $\begin{array}{c}P \\
\text { value }\end{array}$ \\
\hline $\begin{array}{l}\text { Diarrhea } \\
\text { Incidence }\end{array}$ & $77.9 \%$ & $83 \%$ & $100 \%^{\mathrm{a}}$ & $75.0 \%{ }^{b}$ & 1.33 & $1.03-1.59$ & 0.05 \\
\hline $\begin{array}{l}\text { Respiratory } \\
\text { disease Incidence }\end{array}$ & $49.6 \%$ & $56.6 \%$ & $76.50 \%{ }^{\mathrm{a}}$ & $47.20 \%^{\mathrm{b}}$ & 1.62 & $1.04-2.50$ & 0.04 \\
\hline $\begin{array}{l}\text { Recurrence of } \\
\text { diarrhea }\end{array}$ & $36.3 \%$ & $37.7 \%$ & $58.8 \%^{\mathrm{a}}$ & $27.8 \%{ }^{\mathrm{b}}$ & 2.11 & $1.09-4.09$ & 0.03 \\
\hline $\begin{array}{l}\text { Recurrence of } \\
\text { respiratory disease }\end{array}$ & $37.9 \%$ & $20.8 \%$ & $29.40 \%$ & $16.70 \%$ & 1.76 & $0.66-4.97$ & 0.28 \\
\hline Death by diarrhea & $6.9 \%$ & $13.2 \%$ & $23.50 \%$ & $8.30 \%$ & 2.83 & $0.70-11.24$ & 0.12 \\
\hline $\begin{array}{l}\text { Death by } \\
\text { respiratory disease }\end{array}$ & $4.6 \%$ & $7.5 \%$ & $11.76 \%$ & $5.55 \%$ & 2.11 & $0.32-13.7$ & 0.42 \\
\hline Overall death & $10.7 \%$ & $17 \%$ & $29.40 \%$ & $11.10 \%$ & 2.64 & $0.81-8.62$ & 0.09 \\
\hline Diarrhea lethality & $7.8 \%$ & $11.3 \%$ & $17.65 \%$ & $8.33 \%$ & 2.11 & $0.47-9.42$ & 0.31 \\
\hline $\begin{array}{l}\text { Respiratory } \\
\text { disease lethality }\end{array}$ & $9.4 \%$ & $7.8 \%$ & $11.76 \%$ & $5.88 \%$ & 2.0 & $0.30-12.99$ & 0.46 \\
\hline
\end{tabular}

$P$ values are derived from Pearson's chi square tests and are considered significant when $P \leq 0.05$. Different superscript letters indicate that there are statistical differences between cohorts. 




Figure 1. Survival curves for the interval from birth to 60 days of life, for diarrhea disease. Cows with FPIT had ( $\mathrm{P}=0.02$ ) greater rate of diarrhea (adjusted hazard ratio=2,68; $95 \% \mathrm{CI}=1.27$ to 5.65 ) compared with calves without FPIT

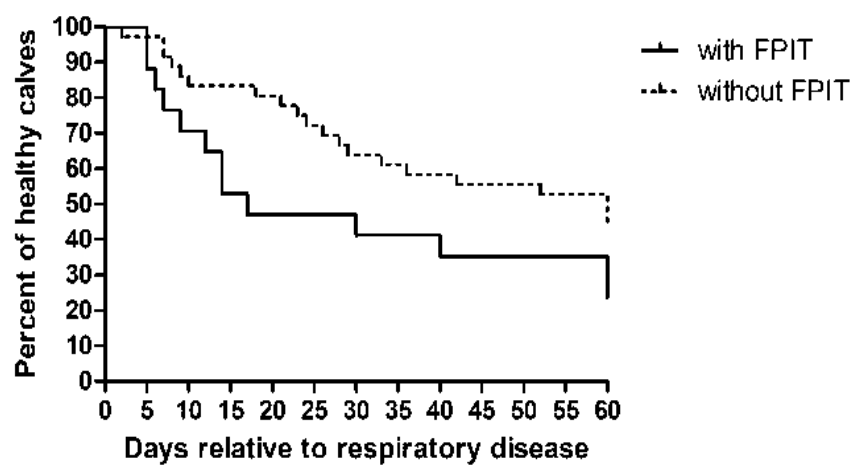

Figure 2 Survival curves for the interval from birth to 60 days of life, for respiratory disease. No differences were found between groups $(\mathrm{P}=0.11)$.

Throughout the study, the percentage of deaths due to diarrhea was $6.9 \%(9 / 131)$, and deaths due to respiratory disease was $4.6 \%(6 / 131)$. The total number of deaths was $10.7 \%(14 / 131)$. One calf died of both, respiratory disease and diarrhea. There was a tendency for a higher death rate in calves with a failure of passive immune transfer when compared to calves with adequate passive immune transfer $(29.40 \%$ vs. $11.10 \%, \mathrm{P}=0.09)$, and animals with FPIT presented 2.64 greater chance of death in relation to those with successful passive immune transfer $(\mathrm{RR}=2.64$, $95 \% \mathrm{CI}=0.81-8.62)$.

Calves mean birth weight were $39.92 \pm 2.83 \mathrm{~kg}$ $(\mathrm{n}=131)$. Mean weight gain throughout the study was $35.48 \pm 8.9 \mathrm{~kg}(\mathrm{n}=117)$, while average daily gain $(\mathrm{ADG})$ was $0.603 \pm 0.15 \mathrm{~kg}(\mathrm{n}=117)$. After 60 days of the experiment, $36.8 \% \quad(n=43 / 117)$ of animals doubled their weight compared to their birth weight.

Comparisons between calves that did not present FPIT versus those with FPIT showed no differences in all evaluations (weight, wither height, width of the croup and thoracic perimeter) performed on days 1, 7, 14, 21, 28 and 60 $(\mathrm{P}>0.05)$ As a consequence, the same pattern occurred for ADG $(\mathrm{P}=0.73)$, where calves with FPIT presented similar values (ADG: $0.64 \pm 0.60 \mathrm{~kg}$ ) compared to calves that did not present FPIT (ADG: $0.62 \pm 0.48 \mathrm{~kg}$ ). Also, there were no differences in relation to percentage of calves that doubled their weight at the end of 60 days of study. Zootechnical differences have been observed over the weeks. (Table 2). 
Table 2. Zootechnical performance of Holstein dairy calves with or without failure of passive immunity transfer (FPIT) in southern Brazil

\begin{tabular}{|c|c|c|c|c|c|c|c|c|c|c|c|c|c|c|c|}
\hline & \multicolumn{2}{|c|}{ Born } & \multicolumn{2}{|c|}{7 days } & \multicolumn{2}{|c|}{14 days } & \multicolumn{2}{|c|}{21 days } & \multicolumn{2}{|c|}{28 days } & \multicolumn{2}{|c|}{60 days } & \multirow{2}{*}{ 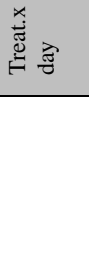 } & \multirow{2}{*}{$\begin{array}{l}\vec{J} \\
\text { a }\end{array}$} & \multirow{2}{*}{$\begin{array}{l}\vec{\Xi} \\
\Xi \\
2\end{array}$} \\
\hline & 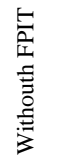 & 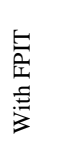 & 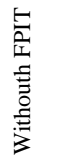 & 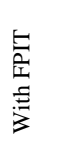 & 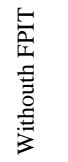 & 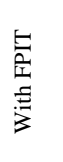 & 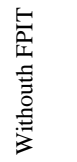 & 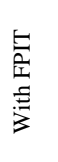 & 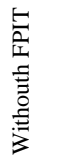 & $\begin{array}{l}E \\
\text { 空 } \\
\vdots \\
\vdots\end{array}$ & 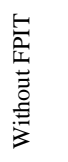 & 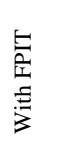 & & & \\
\hline $\begin{array}{l}\mathrm{B} \\
\mathrm{W}\end{array}$ & $\begin{array}{l}40.0 \\
\pm \\
0.35\end{array}$ & $\begin{array}{l}40.2 \\
\pm \\
0.53\end{array}$ & $\begin{array}{l}42.7 \\
\pm \\
0.35\end{array}$ & $\begin{array}{l}42.7 \\
\pm \\
0.53\end{array}$ & $\begin{array}{l}45.2 \\
\pm \\
0.36\end{array}$ & $\begin{array}{l}44.6 \\
\pm \\
0.53\end{array}$ & $\begin{array}{l}49.1 \\
\pm \\
10.37\end{array}$ & $\begin{array}{l}47.7 \\
\pm \\
0.6\end{array}$ & $\begin{array}{l}53.3 \\
\pm \\
0,37\end{array}$ & $\begin{array}{l}52.6 \\
\pm \\
0.61\end{array}$ & $\begin{array}{l}77.8 \\
\pm \\
0.37\end{array}$ & $\begin{array}{l}76.3 \\
\pm \\
0.63\end{array}$ & 0.42 & $<0.01$ & 0.68 \\
\hline $\begin{array}{l}\mathrm{T} \\
\mathrm{P}\end{array}$ & $\begin{array}{l}75.5 \\
\pm \\
0.10\end{array}$ & $\begin{array}{l}75.7 \\
\pm \\
0.15\end{array}$ & $\begin{array}{l}77.4 \\
\pm \\
0.10\end{array}$ & $\begin{array}{l}77.9 \\
\pm \\
0.15\end{array}$ & $\begin{array}{l}79.3 \\
\pm \\
0.11\end{array}$ & $\begin{array}{l}78.8 \\
\pm \\
0.15\end{array}$ & $\begin{array}{l}82.2 \\
\pm \\
0.11\end{array}$ & $\begin{array}{l}81.1 \\
\pm \\
0.18\end{array}$ & $\begin{array}{l}84.1 \\
\pm \\
0.11\end{array}$ & $\begin{array}{l}84 \\
\pm \\
0.18\end{array}$ & $\begin{array}{l}95 \\
\pm \\
0.11\end{array}$ & $\begin{array}{l}93.8 \\
\pm \\
0.19\end{array}$ & $<0.01$ & $<0.01$ & 0.74 \\
\hline $\begin{array}{l}\mathrm{W} \\
\mathrm{H}\end{array}$ & $\begin{array}{l}75.05 \\
\pm \\
0.18\end{array}$ & $\begin{array}{l}76.7 \\
\pm \\
0.27\end{array}$ & $\begin{array}{l}76.2 \\
\pm \\
0.18\end{array}$ & $\begin{array}{l}77.8 \\
\pm \\
0.27\end{array}$ & $\begin{array}{l}77.3 \\
\pm \\
0.18\end{array}$ & $\begin{array}{l}78.7 \\
\pm \\
0.27\end{array}$ & $\begin{array}{l}79.3 \\
\pm \\
0.19\end{array}$ & $\begin{array}{l}81 \\
\pm \\
0.31\end{array}$ & $\begin{array}{l}81.4 \\
\pm \\
0.19\end{array}$ & $\begin{array}{l}81.1 \\
\pm \\
0.31\end{array}$ & $\begin{array}{l}87 . \\
8 \pm \\
0.19\end{array}$ & $\begin{array}{l}88.4 \\
\pm \\
0.32\end{array}$ & $<0.01$ & $<0.01$ & 0.24 \\
\hline $\begin{array}{l}\text { W } \\
\text { C }\end{array}$ & $\begin{array}{l}22 \\
\pm \\
0.53\end{array}$ & $\begin{array}{l}21.2 \\
\pm \\
0.78\end{array}$ & $\begin{array}{l}22.7 \\
\pm \\
0.53\end{array}$ & $\begin{array}{l}21.8 \\
\pm \\
0.78\end{array}$ & $\begin{array}{l}23.3 \\
\pm \\
0.54\end{array}$ & $\begin{array}{l}22.3 \\
\pm \\
0.78\end{array}$ & $\begin{array}{l}25 . \\
5 \pm \\
0.55\end{array}$ & $\begin{array}{l}23.6 \\
\pm \\
0.9\end{array}$ & $\begin{array}{l}24.5 \\
\pm \\
0.55\end{array}$ & $\begin{array}{l}24.25 \\
\pm \\
0.9\end{array}$ & $\begin{array}{l}27.53 \\
\pm \\
0.55\end{array}$ & $\begin{array}{l}27.18 \\
\pm \\
0.94\end{array}$ & 0.92 & $<0.01$ & 0.27 \\
\hline
\end{tabular}

$\mathrm{BW}=$ body weight; $\mathrm{TP}=$ Thoracic perimeter, $\mathrm{WH}=$ withers height and $\mathrm{WC}=$ Width of the croup Results are expressed as means \pm standard error. $P$ values $\leq 0.05$ are considered significant. We used repeated measure analysis of variance.

\section{DISCUSSION}

When calves receive satisfactory amounts of quality colostrum, total protein concentration will be $5.4 \mathrm{~g} / \mathrm{dL}$ or more. In our study, we considered that FPIT calves had TPP concentrations below $5.5 \mathrm{~g} / \mathrm{dL}$ (Buczinski et al., 2018). Thus, we found higher failure of passive immune transfer rates $(32.07 \%)$ than those previously described by Feitosa et al. (2001), who observed FPIT rates between $22 \%$ and $25 \%$, when values of $5.5 \mathrm{~g} / \mathrm{dL}$ were used as a cutoff. However, our rates are very close to $34.6 \%$, observed by Lora et al. (2018), in commercial dairy farms in Italy. In the first study (Feitosa et al., 2001), the location of the study was not described, but evaluations were performed on 40 male and female Holstein calves, which remained with their mothers for a period up to 24 hours (16 to 24 hours), ingesting colostrum ad libitum, with serum evaluations performed at 24 hours of life.

According to Weaver et al. (2000) and Zakian et al. (2018), the 5.5-g/dL cutoff may be preferable in clinically ill calves. In a healthy adequately hydrated calf a serum total protein of $5.2 \mathrm{~g} / \mathrm{dL}$ or greater is associated with adequate passive transfer. For this reason, some variations in percentage of calves with FPIT may be observed, depending on the cutoff used. Besides differences in methodology used to measure $\mathrm{IgG}$ concentration by different studies, the methodology used by us (refractometry) provides an indirect measure that is highly correlated with blood IgG concentration and is more practical for use on-farm (Wilm et al. 2018).

One satisfactory ingestion of quality colostrum is essential to protect neonates against pathogens during their first weeks of life (Chase et al., 2008), since it has compounds such as antibodies and several immune cells (Godden, 2008) that are known to increase the mechanisms of defense in the neonate (Cortese, 2009). Our study has shown that when calves receive a satisfactory amount of Igs from colostrum, the occurrence of diseases like diarrhea and respiratory disease are reduced. The importance of feeding colostrum to prevent development of diseases has already been demonstrated in several studies.

In a study carried out by Arsenopoulos et al. (2017), the effect of colostrum ingestion on the occurrence of diarrhea caused by Cryptosporidium spp. Was determined, and failures in the quantity and quality of colostrum supplied to neonates have been related to an increase in the occurrence of cryptosporidiosis. Bok et al. (2018) showed that calves that had received a satisfactory absorption of colostrum from calves vaccinated against bovine coronavirus (BcoV) had less percent of 
soroconversion to $\mathrm{BcoV}$ when contrasted to calves that had not received a satisfactory passive immune transfer, indicating that calves without FPIT are more protected against viral infection. The same results were observed by Foster $e t$ al. (2019) who also demonstrated that calves receiving colostrum from cows vaccinated against Salmonella sp. had higher serum titers, but in this study, higher titers were not sufficient to protect against disease development. As we saw in our study, Lora et al. (2018) have also found that FPIT directly influences the incidence of diarrhea in neonates, and it is a risk factor for mortality in animals.

Considering the $23 \%$ incidence of diarrhea in a study with newborn calves on farms in Canada and the United States (Windeyer et al., 2014), the percentage of animals with diarrhea in this study was high $(77.9 \%)$. However, it is in accordance with the Brazilian reality, where the incidence of diarrhea has ranged from 53.65 to $100 \%$ (Langoni et al., 2004). The large variation in morbidity rates for different diseases in Brazil is a reflection on the diversity of milk production systems in the country. Santos and Bittar (2015) have carried out surveys related to production systems in different states of Brazil, such as: São Paulo, Paraná, Minas Gerais, Ceará, Goiás, and Distrito Federal, showing differences in milk production at different farms, in drying processes of the cows, in location of maternity pens, in volume of colostrum supplied (many offered colostrum volumes below the recommended level), among others. All these differences in management are factors that, to a greater or lesser degree, influence the development of diseases, therefore, justifying the great variation of disease incidences in Brazilian herds.

In our study, the only differences between farm structures are linked to calves' houses. However, when we contrasted farms with individual calf pen or stake system, there were no differences on occurrence of diarrhea. We also didn't observe differences on incidence of diarrhea when all farms were compared (incidence range from $76.9 \%$ to $88.9 \%$ ). This leads us to believe that there are many different factors that are influencing the high occurrence of diarrhea, such as high rates of FPIT, management failures, and climate, and all these factors may interact with each other interfering in disease incidence. The reduced number of calves with passive immunity transfer evaluation in this study may also have contributed to no statistical differences.

Our study has shown a greater tendency of death due to diarrhea in calves that presented deficits in immunoglobulins transfer. This is in accordance to Chigerwe et al. (2009), who have demonstrated that calves that do not receive colostrum are 74 times more likely to die within the first three weeks of life. Moreover, we have observed that calves with FPIT are 1.33 times more likely to develop diarrhea, and 1.62 times more likely to develop respiratory disease. This is because colostral immunoglobulins provide a double line of passive immunological defense for the calf, providing protection against both septicemia and enteric disease. Defense against enteric infection appears to be predominantly a local effect involving $\operatorname{IgA}$ as the principle immunoglobulin acting at the paramucosal surface, but this localized protection may involve other immunoglobulins as well. Immunoglobulins IgM and $\mathrm{IgG}$ in the neonatal serum are generally regarded primarily as protective against septicemia, especially against Escherichia coli (Rischen, 1981). The severity of diarrhea has also been related to failures in immune transfer (Furman-Fratczak et al., 2011).

A morbidity rate of $7.6 \%$ and a mortality rate of around $2.3 \%$ for respiratory diseases have been reported by Sivula et al. (1996), in calves from birth to 14 weeks of age, in Minnesota State. According to the United States Department of Agriculture, incidence of respiratory diseases in this category has remained around $20 \%$ (Heifer..., 2007), with respiratory diseases accounting for about $24 \%$ of deaths in suckled calves, and $58.9 \%$ of deaths in weaned calves; these values are lower than those found in our study, where the incidence of respiratory disease was $49.6 \%$, with a death rate of $4.6 \%$. Differences in incidence rates between studies can occur due to influence of geographic factors, climate, farm size, type of system, feeding, and genetics (Gulliksen et al., 2009).

All the farms included in the study are under humid subtropical climate, characterized by hot and humid summers, and cool to mild winters, and the medium temperatures in winter and summer are, respectively, $13^{\circ} \mathrm{C}$ and $24^{\circ} \mathrm{C}$. The climate may have interfered with the occurrence of diseases, especially in the properties that kept the calves exposed to the elements (stake system - 2 
from 5 farms). Calves in this case are susceptible to thermic stress, and it can lead to hyper- or hypothermia, and in extreme cases death (Roland et al., 2016). At the same time, we could observe that some calves in individual calf pens were under bad air conditions, with high concentration of ammonia or poor ventilation. According to Rolland et al. (2016), all these factors may contribute to respiratory disease. Daily follow-up in the farms in this study allowed us to diagnose both bronchitis and pneumonia, and these early diagnoses may also have contributed to a high incidence of respiratory diseases, as well as high FPIT indexes, compared to North American data.

Besides, studies have shown that both diarrhea and respiratory diseases may cause great financial losses to the breeding system due to treatment costs and animal losses, as well as several negative effects on zootechnical performance of future dairy cattle, which includes low growth, decreased reproductive performance, decreased milk production, and decreased longevity (Poulsen and Mcguirk, 2009). We have not found a difference in animal weight gain or a difference in other growth parameters between animals with or without FPIT, and since a veterinarian was always caring for the animals, and always providing care when a disease was diagnosed, the animals were quickly treated in such a way that a difference in zootechnical performance was not evident.

Regarding losses generated by FPIT, an experiment carried out with 3,479 calves showed that FPIT was responsible for more than $40 \%$ of animal deaths (Tyler et al., 1999), and economic consequences were estimated to be $€ 52$ (best case scenario) to $€ 285$ (worst case scenario) (Raboisson et al., 2016). In our study, economic analysis was not performed, however, we noticed that there was a higher incidence of respiratory diseases in calves with FPIT. In addition, calves with FPIT presented a higher incidence of diarrhea and higher diarrhea recurrence, corroborating the literature, which demonstrates that FPIT is directly related to economic losses within the farms.

Thus, the importance of adequate passive immune transfer to dairy calves' health has been demonstrated in this study. Ensuring adequate passive immune transfer to calves is extremely relevant to reduce costs, because it reduces the risk of severe infections and decreases the need of using drugs. Furthermore, data related to the incidence of diseases in calves in Rio Grande do Sul State is extremely important, because it can provide a more concrete idea on the situation of animal health in commercial dairy farms, allowing the development of prevention and control strategies.

From this point of view, we may conclude that diarrhea and respiratory diseases are disorders with a high incidence in bovine neonates from dairy farms in Rio Grande do Sul. FPIT increases the risks of calves in individual management, developing diarrhea in $33 \%$ and respiratory disease in $62 \%$, but does not impact animal performance. This study serves as a warning for the high rate of failure in passive immunity transfer and disease in Brazilian commercial dairy farms.

\section{ACKNOWLEDGEMENTS}

The authors thank Conselho Nacional de Pesquisa $(\mathrm{CnPq})$ for its financial support. Special acknowledgments to Instituto Federal do Rio Grande do Sul (IFRS) for qualification support.

\section{REFERENCES}

ARSENOPOULOS, K.; THEODORIDIS, A.; PAPADOPOULOS, E. Effect of colostrum quantity and quality on neonatal calf diarrhea due to Cryptosporidium spp. infection. Comp. Immunol. Microbiol. Infect. Dis., v.53, p.50-55, 2017.

BOK, M.; ALASSIA, M.; FRANK, F. et al. Passive immunity to control bovine coronavirus diarrhea in a dairy herd in Argentina. Rev. Argent. Microbiol., v.50, p.23-30, 2018.

BUCZINSKI, S.; GICQUEL, E.; FECTEAU, G. et al. Systematic review and meta-analysis of diagnostic accuracy of serum refractometry and brix refractometry for the diagnosis of inadequate transfer of passive immunity in calves. J. Vet. Intern. Med., v.32, p.474-483, 2018.

CHASE, C.C.L.; HURLEY, D.J.; REBER, A.J. neonatal immune development in the calf and its impact on vaccine response. Vet. Clin. N. Am. Food Anim. Pract., v.24, p.87-104, 2008. 
CHIGERWE, M.; TYLER, J.W.; SUMMERS, M.K. et al. Evaluation of factors affecting serum IgG concentrations in bottle-fed calves. J. Am. Vet. Med. Assoc., v.234, p.785-789, 2009.

CORTESE, V.S. Neonatal immunology. Vet. Clin. N. Am. Food Anim. Pract., v.25, p.221-227, 2009.

COSTA, J.H.C.; VON KEYSERLINGK, M.A.G.; WEARY, D.M. Invited review: Effects of group housing of dairy calves on behavior, cognition, performance, and health. J. Dairy Sci., v.99, p.2453-2467, 2016.

DEAN, A.; SULLIVAN, K.; SOE, M. OpenEpi: open source epidemiological statistics for public health, version 3.01, 2014.

DIRKSEN, G.; GRÜNDER, H.; STÖBER, M. Rosenberger, exame clínico dos bovinos. In: DIRKSEN, G. Sistema digestivo. Rio de Janeiro: Guanabara Koogan, 1993. p.166-228.

FEITOSA, F.L.F.; BIRGEL, E.H.; MIRANDOLA, R.M.S.; PERRI, S.H.V. Diagnóstico de falha de transferência de imunidade passiva em bezerros através da determinação de proteína total e de suas frações eletroforéticas, imunoglobulinasgeme da atividade dagamaglutamil transferase no soro sanguíneo. Ciênc. Rural, v.31, p.251-255, 2001.

FLEISS, J.L.; LEVIN, B.; PAIK, M.C. Statistical methods for rates and proportions. Hoboken: John Wiley \& Sons, 2013.

FOSTER, D.; JACOB, M.; STOWE, D. et al. Exploratory cohort study to determine if dry cow vaccination with a Salmonella Newport bacterin can protect dairy calves against oral Salmonella challenge. J. Vet. Intern. Med., v.33, p.1796, 2019.

FURMAN-FRATCZAK, K.; RZASA, A.; STEFANIAK, T. The influence of colostral immunoglobulin concentration in heifer calves' serum on their health andgrowth. J. Dairy Sci., v.94, p.5536-5543, 2011.

GODDEN, S. Colostrum management for dairy calves. Vet. Clin. N. Am. Food Anim. Pract., v.24, p.19-39, 2008.

GOMES, V.; BACCILLI, C.C.; MARTIN, C.C. et al. Colostro bovino: muito além das imunoglobulinas. Rev. Acad. Ciênc. Anim., v.15, Supl.2, p.s99-108, 2017.
GULLIKSEN, S.M.; LIE, K.I.; LØKEN, T.; OSTERAS, O. Calf mortality in Norwegian dairy herds. J. Dairy Sci., v.92, p.2782-2795, 2009.

HEIFER calf health and management practices on US dairy operations, 2007. Washington: APHIS, ed. Dairy. Available in: <https://www.aphis.usda.gov/aphis/ourfocus/ani malhealth/monitoring-andsurveillance/nahms/nahms_dairy_studies>. Accessed in: 5 Mar 2019.

HEINRICHS, A.; ERB, H.; ROGERS, G. et al. Variability in Holstein heifer heart-girth measurements and comparison of prediction equations for live weight. Prev. Vet. Med., v.78, p.333-338, 2007.

LANGONI, H.; LINHARES, A.C.; AVILA, F.A. et al. Contribution to the study of diarrhea etiology in neonate dairy calves in São Paulo State, Brazil. Braz. J. Vet. Res. Anim. Sci., v.41, p.313-319, 2004.

LORA, I.; GOTTARDO, F.; CONTIERO, B. et al. Association between passive immunity and health status of dairy calves under 30 days of age. Prev. Vet. Med., v.152, p.12-15, 2018.

LORENZ, I.; MEE, J.F.; EARLEY, B.; MORE, S.J. Calf health from birth to weaning. I. general aspects of disease prevention. Ir. Vet. J., v.64, p.10, 2011.

MacFARLANE, J.A.; GROVE-WHITE, D.H.; ROYAL, M.D.; SMITH, R.F. Identification and quantification of factors affecting neonatal immunological transfer in dairy calves in the UK. Vet. Rec., v.24, p.625-625, 2015.

MORRISON, S.; SCOLEY, G.; BARLEY, J. The impact of calf health on future performance. Vet. Irel. J., v.3, p.264-268, 2013.

POULSEN, K.P.; McGUIRK,S.M. Respiratory disease of the bovine neonate. Vet. Clin. N. Am. Food Anim. Pract., v.25, p.121-137, 2009.

QUIGLEY III, J.D.; MARTIN, K.R.; BEMIS, D.A. et al. Effects of housing and colostrum feeding on serum immunoglobulins, growth, and fecal scores of Jersey calves. J. Dairy Sci, v. 78, n. 4, p. 893-901, 1995.

RABOISSON, D.; TRILLAT, P.; CAHUZAC, C. Failure of passive immune transfer in calves: a meta-analysis on the consequences and assessment of the economic impact. PloS One, v.11, p.e0150452, 2016. 
RISCHEN, C.G. Passive immunity in the neonatal calf. Iowa State Univ. Vet., v.43, p.1, 1981.

ROLAND, L.; DRILLICH, M.; KLEIN-JÖBSTL, D. et al. Invited review: Influence of climatic conditions on the development, performance, and health of calves. J. Dairy Sci., v.99, p.2438-2452, 2016.

SANTOS, G.; BITTAR, C.M.M. A survey of dairy calf management practices in some producing regions in Brazil. Rev. Bras. Zootec., v.44, p.361-370, 2015.

SIVULA, N.; AMES, T.; MARSH, W. WERDIN, R. Descriptive epidemiology of morbidity and mortality in Minnesota dairy heifer calves. Prev. Vet. Med., v.27, p.155-171, 1996.

SMOLENSKI, G.; HAINES, S.; KWAN, F.Y.S. et al. Characterization of host defense proteins in milk using a proteomic approach. J. Proteome Res., v.6, p.207-215, 2007.

TYLER, J.W.; HANCOCK, D.D.; THORNE, J.G. et al. Partitioning the mortality risk associated with inadequate passive transfer of colostral immunoglobulins in dairy calves. J. Vet. Intern. Med., v.13, p.335-337, 1999.
WEAVER, D.M.; TYLER, J.W.; VANMETRE, D.C. et al. Passive transfer of colostral immunoglobulins in calves. J. Vet. Intern. Med., v.14, p.569-577, 2000.

WILM, J.; COSTA, J.H.; NEAVE, H.W. et al. Serum total protein and immunoglobuling concentrations in neonatal dairy calves over the first 10 days of age. J. Dairy Sci., v.101, p.64306436, 2018.

WINDEYER, M.; LESLIE, K.;gODDEN, S. et al. Factors associated with morbidity, mortality, andgrowth of dairy heifer calves up to 3 months of age. Prev. Vet. Med., v.113, p.231-240, 2014.

ZAKIAN, A.; NOURI, M.; RASOOLI, A. et al. Evaluation of 5 methods for diagnosing failure of passive transfer in 160 Holstein calves. Vet. Clin. Pathol., v.47, p.275-283, 2018. 